\title{
Xenogeneic collagen matrix for the treatment of multiple gingival recessions in esthetics areas: a case series with 24-month follow-up
}

Matriz xenógena para o tratamento de recessões gengivais múltiplas em áreas estéticas: uma série de casos com 24 meses de acompanhamento

Matriz de colágeno xenogénico para el tratamiento de múltiples recesiones gingivales en áreas estéticas: serie de casos a los 24 meses

\author{
Raphaella Coelho Michel \\ ORCID: https://orcid.org/0000-0003-0878-1502 \\ University of São Paulo, Brazil \\ E-mail: raphaellamichel@gmail.com \\ Rafael Ferreira \\ ORCID: https://orcid.org/0000-0001-5879-2782 \\ University of São Paulo, Brazil \\ E-mail: rafael_ferreira@ufms.br \\ Érika Beatriz Spada de Carvalho \\ ORCID: https://orcid.org/0000-0003-2513-3240 \\ University of São Paulo, Brazil \\ E-mail: erika_spada@hotmail.com \\ Talyta Sasaki Jurkevicz \\ ORCID: https://orcid.org/0000-0001-5050-7094 \\ University of São Paulo, Brazil \\ E-mail: talyta.s.j@usp.br \\ Carla Andreotti Damante \\ ORCID: https://orcid.org/0000-0002-6782-8596 \\ University of São Paulo, Brazil \\ E-mail: cdamante@usp.br \\ Adriana Campos Passanezi Sant'Ana \\ ORCID: https://orcid.org/0000-0001-5640-9292 \\ University of São Paulo, Brazil \\ E-mail: acpsantana@usp.br \\ Mariana Schutzer Ragghianti Zangrando \\ ORCID: https://orcid.org/0000-0003-0286-7575 \\ University of São Paulo, Brazil \\ E-mail: mariana@fob.usp.br
}

\begin{abstract}
Introduction: Multiple gingival recessions (GR) are often associated with high hypersensitivity and esthetics concerns due to exposed roots. The collagen matrix (CM) associated with coronally advanced flap (CAF) may be a suitable treatment for multiple GR in esthetic areas. However, there is a lack of long term follow up investigations. Objective: To evaluate a 24-month follow-up of the CM + CAF treatment for multiple RT1 GRs in esthetics areas. Materials and Methods: Six patients presenting 6 adjacent Cairo's gingival recessions type 1 (RT1) in the anterior maxilla were treated with $\mathrm{CM}+\mathrm{CAF}$, and based on these patients a brief statistical analysis was conduct. The evaluated parameters included gingival recession depth (GRD), gingival recession width (GRW), probing depth (PD), clinical attachment level (CAL), keratinized tissue width (KTW), gingival thickness (GT), and mean root coverage (MRC). Patientrelated outcomes measurements (PROMs) were assessed using an oral health impact profile (OHIP-14) questionnaire and visual analogue scale (VAS). Results: There was significant improvement in GRD, GRW, and CAL measurements at 3 months postoperatively $(p<0.05)$. Besides, CAL also increased from 12 months to 24 months' follow-up ( $p=0.0023)$. The MRC percentage was $82 \%$. PD, GT, and KTW presented no statistical difference. PROMs revealed a high score for esthetics $(82.2 \%)$ and a significant reduction in hypersensitivity and surgical pain/discomfort. Conclusions: Considering the limitations of a case series, the use of CM + CAF on RT1 multiple gingival recessions in esthetic areas demonstrated positive outcomes after 24 months.
\end{abstract}

Keywords: Biomaterials; Esthetics; Gingival recession; Periodontal disease; Case series; Periodontics.

\section{Resumo}

Introdução: Recessões gengivais múltiplas (RG) estão frequentemente associadas a alta hipersensibilidade e preocupações estéticas devido as raízes expostas. A matriz de colágeno (MC) associada ao retalho avançado 
coronalmente (CAF) pode ser um tratamento adequado para RG múltiplas em áreas estéticas. No entanto, há uma carência de investigações para o acompanhamento a longo prazo. Objetivo: Avaliar o comportamento de 24 meses de acompanhamento da MC + CAF no tratamento de RGs RT1 múltiplas em áreas estéticas. Materiais e Métodos: Seis pacientes apresentando 6 recessões adjacentes do tipo 1 do Cairo (RT1) na maxila anterior foram tratados com CM + CAF. Os parâmetros avaliados incluíram profundidade da recessão gengival (GRD), largura da recessão gengival (GRW), profundidade de sondagem (PD), nível de inserção clínica (CAL), largura do tecido queratinizado (KTW), espessura gengival (GT) e cobertura média da raiz (MRC). As medidas dos parâmetros centrados no paciente (PROMs) foram avaliadas por meio de um questionário de perfil de impacto na saúde bucal (OHIP-14) e escala visual analógica (VAS). Resultados: Houve melhora significativa nas medidas de GRD, GRW e CAL em 3 meses de pósoperatório $(\mathrm{p}<0,05)$. Além disso, o CAL também aumentou de 12 meses para 24 meses de acompanhamento ( $\mathrm{p}=$ 0,0023). O percentual de MRC foi de $82 \%$. PD, GT e KTW não apresentaram diferença estatística. Os PROMs revelaram uma pontuação elevada para a estética $(82,2 \%)$ e uma redução significativa da hipersensibilidade e da dor / desconforto cirúrgico. Conclusões: Considerando as limitações de uma série de casos, o uso de CM + CAF em recessões gengivais RT1 múltiplas em áreas estéticas demonstrou resultados positivos após 24 meses.

Palavras-chave: Biomateriais; Estética; Recessão gengival; Doença periodontal; Série de casos; Periodontia.

\section{Resumen}

Introducción: Las recesiones gingivales múltiples (RG) a menudo se asocian con una alta hipersensibilidad y preocupaciones estéticas debido a las raíces expuestas. La matriz de colágeno (MC) asociada al colgajo coronalmente avanzado (CAF) puede ser un tratamiento adecuado para múltiples GR en áreas estéticas. Sin embargo, faltan investigaciones de seguimiento a largo plazo. Objetivo: Evaluar un seguimiento de 24 meses del CM $+\mathrm{CAF}$ sobre el tratamiento de múltiples RT1 GR en áreas de estética. Materiales y métodos: Se trató con CM + CAF a seis pacientes que presentaban 6 recesiones adyacentes tipo 1 (RT1) de El Cairo en el maxilar anterior. Los parámetros evaluados incluyeron profundidad de recesión gingival (GRD), ancho de recesión gingival (GRW), profundidad de sondaje (PD), nivel de inserción clínica (CAL), ancho del tejido queratinizado (KTW), grosor gingival (GT) y cobertura radicular media (MRC). Las mediciones de resultados relacionados con el paciente (PROM) se evaluaron mediante un cuestionario de perfil de impacto en la salud bucal (OHIP-14) y una escala analógica visual (VAS). Resultados: Hubo una mejora significativa en las mediciones de GRD, GRW y CAL a los 3 meses de la operación (p <0.05). Además, CAL también aumentó de 12 meses a 24 meses de seguimiento $(\mathrm{p}=0,0023)$. El porcentaje de MRC fue del 82\%. PD, GT y KTW no presentaron diferencia estadística. Las PROM revelaron una puntuación alta en estética $(82,2 \%)$ y una reducción significativa de la hipersensibilidad y el dolor / malestar quirúrgico. Conclusiones: Considerando las limitaciones de una serie de casos, el uso de CM + CAF en recesiones gingivales múltiples RT1 en áreas estéticas demostró resultados positivos a los 24 meses.

Palabras clave: Biomateriales; Estética; Recesión gingival; Enfermedad periodontal; Serie de casos; Periodoncia.

\section{Introduction}

The fundamental purpose of periodontal plastic surgery is to reestablish a patient's oral health by recovering the function and esthetics of the periodontal apparatus. Gingival recession (GR) is characterized by the displacement of the gingival margin (GM) apical to the cementoenamel junction (CEJ) and consequently root exposure (Armitage, 1999). The demand for esthetic dentistry has significantly increased and GR is one of the main complaints and reasons for root coverage (RC) procedures (Wennström, 1996). Several surgical techniques were proposed for GR treatment, such as laterally positioned flap (LPF), double papilla flap (DPF), coronally advanced flap (CAF) associated or not with subepithelial connective tissue graft (SCTG) (Cairo, 2017). However, the gold standard treatment for Miller's Class I and II or Cairo's recession type 1 (RT1) (Cairo et al., 2011) is the SCTG associated with coronally advanced flap (Chambrone et al., 2019). Nevertheless, SCTG may present superior postoperative morbidity (two surgical sites), a limited amount of donor tissue, and increased surgical time (Oates et al., 2003). These factors are considered substantial disadvantages of autogenous grafts and the main reason for the development of tissue substitutes (Zuhr et al., 2014).

During the past decade, the collagen matrix (CM) (Mucograft ${ }^{\circ}$, Geistlich Pharma AG, Switzerland) was widely studied as an alternative for SCTG. This CM is a resorbing porcine double-layer matrix with a three-dimensional conformation of types I and III collagen. Studies with this CM presented satisfactory results for the treatment of periodontal and implant recession defects (Sanz et al., 2009; McGuire \& Scheyer, 2010). 
Although extensively discussed in the literature, few studies have evaluated the long-term stability of the CM in multiple gingival recessions, especially in esthetic areas (Chambrone et al., 2019). Therefore, the objective of the present case series was to evaluate the stability of CM associated with CAF in the treatment of Cairo RT1 (Miller's class I and II) multiple gingival recessions in esthetic areas after 24 months.

\section{Case series and Methodology}

Six healthy and nonsmoker patients ( 3 women and 3 men) were enrolled in this prospective case series with an age range of 31 to 57 years. All included patients presented at least 6 RT1 multiple GR in esthetic areas (uppers canine, central and lateral incisors) and they were treated with CAF $+\mathrm{CM}$, according to CARE guidelines. All treated GR had at least $1 \mathrm{~mm}$ of keratinized tissue. Periodontal parameters were evaluated at baseline and after 3, 6, 12, and 24 months. The chief complaint of all patients was poor esthetics due to root exposure. Patients presented plaque and bleeding indices $\leq 20 \%$ throughout the study period and received periodontal basic procedures before the surgical phase. The informed consent, previously approved by the Institutional Review Board of University of São Paulo, Bauru School of Dentistry (FOB/USP) was assigned by each selected patient before the treatment was performed, following the Declaration of Helsinki (CAAE number: 65054416.4.0000.5417).

\subsection{Periodontal Clinical Parameters}

The gingival recession depth (GRD), the gingival recession width (GRW), the probing depth (PD), the clinical attachment level (CAL), the keratinized tissue width (KTW), the gingival thickness (GT), and the mean percentage of root coverage (MRC) were evaluated. All measurements were performed by a pre-calibrated examiner with a periodontal probe (PCPUNC 15; HuFriedy, Chicago, IL, USA) and an anesthetic needle, endodontic stop/caliper for GT. The examiner was blinded as to the treatments performed and surgical procedures. The measurements were recorded as described: (1) GRD, distance from the CEJ to the gingival margin at the mid-buccal site; (2) GRW, horizontal measure from the mesial to the distal gingival points at the CEJ; (3) PD, distance from the gingival margin to the most apical part of the sulcus; (4) CAL, distance from CEJ to the most apical part of the sulcus; (5) KTW, distance from the gingival margin to the mucogingival junction; (6) GT, $2 \mathrm{~mm}$ apical to the mid-buccal gingival margin, using an anesthetic needle and endodontic stop/caliper perpendicular to the surface, with slight pressure until the hard tissue was reached.

\subsection{Patient-related outcomes measurements (PROMs)}

To assess the qualitative analysis, patients were asked to grade their degree of pain/discomfort, esthetics, hypersensitivity, chewing, and brushing capacity on a Visual Analogue Scale (VAS) line (0-10), marking a vertical line corresponding to 0 for no pain and 10 for the worst degree of pain. Besides, patients were asked if they were fully satisfied or not with the treatment results. The Oral health impact profile (OHIP-14) questionnaire evaluated the oral health impact on the quality of life (Oliveira \& Nadanovsky, 2005). All these measurements were assessed at baseline and after 3, 6, 12, and 24 months.

\subsection{Surgical procedure}

Surgeries were performed by a single specialist surgeon (RCM) at the University of São Paulo, Bauru School of Dentistry (FOB/USP), from 2015 to 2016. The Zucchelli and De Sanctis (2000) technique was selected for the anterior esthetic surgical approach and was identically performed in all patients. All surgical procedures were performed under local anesthesia (Articaine 1: 100 4\%, DFL, New Delhi- India), after rinsing with 0.12\% chlorhexidine gluconate (PerioGard ${ }^{\circledR}$, Colgate, New York- USA) for 1 minute. Oblique and intrasulcular incisions were performed with $15 \mathrm{c}$ scalpel blade (Swann Morton ${ }^{\circledR}$, 
Peynier, France) and a split-full-split thickness flap was raised until the mucogingival junction was reached, with tunneling of the central papillae. Anatomical papillae were de-epithelized and scaling and root planing was conducted. Subsequently, the $\mathrm{CM}$ was stabilized at $1 \mathrm{~mm}$ apically to the cementoenamel junction (CEJ) level and the flap was coronally advanced and sutured with 5-0 Nylon sutures (Ethicon® ${ }^{\circledR}$, Johnson \& Johnson, Somerville, New Jersey- USA). The CM was divided into two equal portions and was completely submerged to the coronally advanced flap in all cases (Fig. 1). For postsurgical care, all patients were instructed as to diet and brushing management, and to rinse for 1 minute with $0.12 \%$ chlorhexidine gluconate (PerioGard ${ }^{\circledR}$, Colgate, New York- USA), for 15 days. Patients received an anti-inflammatory therapy (Dexamethasone $8 \mathrm{mg}$ before surgery, $4 \mathrm{mg}$ after surgery and 100mg Nimesulide for 3 days) and antibiotic therapy (Amoxicillin 500mg for 7 days). The sutures were removed after 14 days and professional cleaning was conducted 1 month after surgery. Brushing trauma was the GR etiology from all 6 patients and they were frequently informed that the treatment long-term success depended on trauma removal. Moreover, patients received proper oral hygiene instructions to avoid brushing trauma and these instructions were reinforced in every follow-up recall. Patients were followed after 3, 6, 12, and 24 months.

Figure 1: Surgical procedure. a) baseline Cairo RCT1 gingival recessions. b) Oblique and intrasulcular incisions. c) deepitalization of the papillae and flap elevation, maintaining the central papillae. d) MG matrix view. e) MG position at the receptor site. f) advanced coronally flap and final suture.
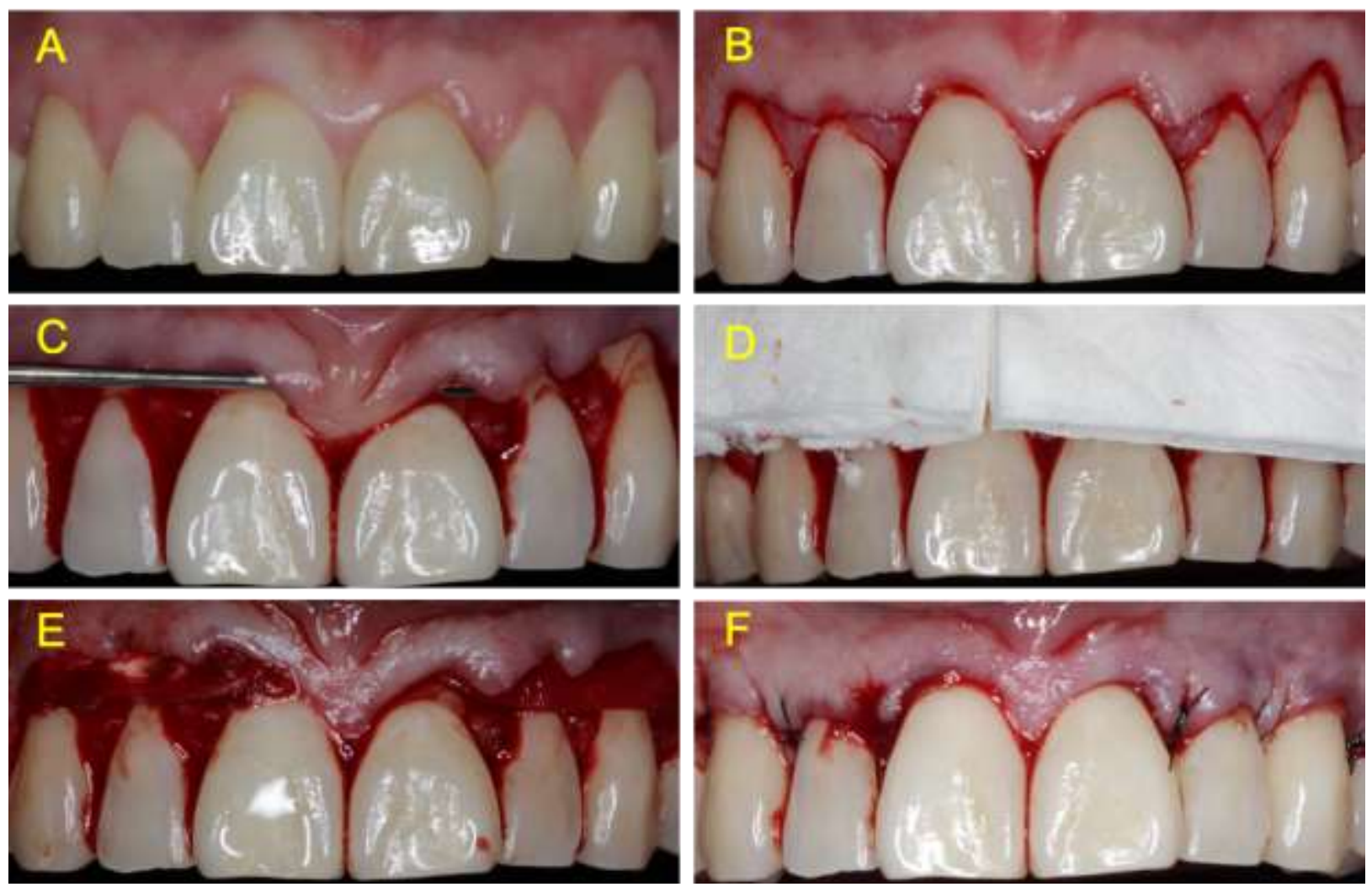

Source: Authors (2019).

\subsection{Statistical analysis}

The intraclass Correlation Coefficient test (ICC) was calculated for the examiner. The percentage of RC was calculated as GR at baseline $-G R$ at 3, 6, 12, and 24 post-ops $\div$ GR at baseline $\times 100$. ANOVA and Turkey tests were conducted by expressed mean \pm SD to evaluate differences in follow-up periods. PROMs analysis involved OHIP-14 
evaluation according to Slade (1997), calculating total value and values of 7 dimensions. A descriptive analysis was conducted for VAS.

\section{Results}

A total of 36 Cairo RT1 gingival recessions on the anterior maxilla were included. The primary outcome (GRD) demonstrated statistically significant reduction after 3 months $(p=0.0023)$. Mean \pm SD values of GRD, GRW, and CAL at baseline and 3, 6, 12, and 24 months showed a significant improvement over time $(p<0.05)$ (Table 1). GRW and GRD significantly decreased from baseline to the last follow-up $(p=0.0023)$. Figures 2 and 3 present clinical changes of GRD and GRW during the follow-up periods. However, CAL had a significant gain in two different periods, showing improvement at 3 months and after 12 to 24 months $(p=0.002)$.

Table 1: Mean \pm SD of the clinical parameters evaluated for CAF + CM treatment over the follow-up periods. For each evaluated parameter, different lowercase letters represent statistical difference $(p<0.05)$. GRW gingival recession width $(p=0.0021)$, KGW keratinized gingival width $(p=0.0022)$, GT gingival thickness $(p=0.0023)$, PD probing depth $(p=0.0031)$, GRD gingival recession depth $(p=0.0023)$, CAL clinical attachment level $(p=0.0022)$.

\section{Clinical Parameters}

\begin{tabular}{|c|c|c|c|c|c|c|}
\hline Time & GRW (mm) & KGW (mm) & GT (mm) & $\mathrm{PD}(\mathrm{mm})$ & GRD (mm) & CAL (mm) \\
\hline \multicolumn{7}{|l|}{ Baseline } \\
\hline Mean \pm SD & $2.89 \pm 0.871^{\mathrm{a}}$ & $3.27 \pm 1.28^{a}$ & $1.02 \pm 0.21^{\mathrm{a}}$ & $2.44 \pm 0.79^{a b}$ & $1.17 \pm 0.44^{\mathrm{a}}$ & $3.39 \pm 0.45^{a b}$ \\
\hline Range & $1.62-4.14$ & $1.17-4.47$ & $0.78-1.36$ & $1.90-4.19$ & $0.28-1.72$ & $2.81-4.22$ \\
\hline \multicolumn{7}{|l|}{3 Mo } \\
\hline Mean \pm SD & $1.37 \pm 1.01^{\mathrm{ab}}$ & $4.24 \pm 1.23^{\mathrm{ab}}$ & $1.30 \pm 0.16^{\mathrm{ab}}$ & $2.08 \pm 2.09^{\mathrm{ab}}$ & $0.34 \pm 0.24^{b}$ & $2.47 \pm 0.09^{a b c}$ \\
\hline Range & $0.00-2.83$ & $2.75-6.13$ & $1.10-1.48$ & $1.76-2.47$ & $0.04-0.61$ & $2.28-2.61$ \\
\hline \multicolumn{7}{|l|}{$6 \mathrm{Mo}$} \\
\hline Mean \pm SD & $0.79 \pm 0.86^{a b}$ & $4.40 \pm 1.48^{\mathrm{ab}}$ & $1.18 \pm 0.06^{\mathrm{ab}}$ & $2.05 \pm 0.32^{\mathrm{ab}}$ & $0.26 \pm 0.25^{b}$ & $2.35 \pm 0.25^{\mathrm{bc}}$ \\
\hline Range & $0.00-2.33$ & $3.00-7.38$ & $1.11-1.29$ & $1.71-2.52$ & $0.04-0.61$ & $1.85-2.61$ \\
\hline \multicolumn{7}{|l|}{$12 \mathrm{Mo}$} \\
\hline Mean \pm SD & $0.83 \pm 0.78^{a b}$ & $4.35 \pm 1.09^{\mathrm{ab}}$ & $1.14 \pm 1.18^{a b}$ & $1.94 \pm 0.36^{a b c}$ & $0.82 \pm 1.85^{b}$ & $2.07 \pm 0.24^{b c}$ \\
\hline Range & $0.00-2.00$ & $3.13-6.00$ & $0.86-1.43$ & $1.61-2.61$ & $0.00-5.00$ & $1.76-2.50$ \\
\hline \multicolumn{7}{|l|}{$24 \mathrm{Mo}$} \\
\hline Mean \pm SD & $0.83 \pm 0.84^{c}$ & $4.37 \pm 0.97^{b}$ & $1.11 \pm 0.19^{b}$ & $1.80 \pm 1.19^{a b c}$ & $0.13 \pm 0.14^{b c}$ & $1.90 \pm 0.11^{d}$ \\
\hline Range & $0.00-2.28$ & $3.00-5.33$ & $0.86-1.37$ & $1.55-2.04$ & $0.00-0.33$ & $1.72-2.09$ \\
\hline
\end{tabular}

Source: Authors (2021).

This change in the CAL parameter demonstrated that even after 1 year of follow-up, the soft tissue presented substantial clinical improvement. There was no statistical difference for KGW, GT, and PD. After 24 months, the percentage of RC for patients 1 to 6 was $93 \%, 69 \%, 77 \%, 67 \%, 89 \%$, and $97 \%$, respectively and the MRC percentage was $82 \%$. Another correlation was made evaluating MRC per type of teeth (right and left canines, lateral and central incisors) in all follow-up 
periods. Right and left canines (groups RCA and LCA) demonstrated a higher MRC over time, and group LCI presented the lowest MRC (Fig. 4). Four patients showed sites of complete root coverage (CRC). Patient \#1 presented 4 sites of CRC. Patient \#2 showed one site of CRC. Patient \#4 presented one site of CRC. Patient \#5 showed 5 sites of CRC. Examiner correlation (ICC) presented excellent agreement for all parameters: GRD (0.981), GRW (0.986), PD (0.949), CAL (0.875), GT (0.886) and KGW (0.912).

Considering PROMs, OHIP-14 presented a significant decrease in all 7 dimensions, showing a great impact on the patient's quality of life over 24 months (Table 2). VAS demonstrated a reduction in hypersensitivity and surgical pain/discomfort $(p<0.05)$. A significant increase was observed in the patient's esthetic perception and chewing/brushing capacity (Table 3).

Figure 2: Right side trend of clinical changes on GR at 3(A), 6(B), 12(C) and 24(D) months. E and D changes at baseline to the last follow up.
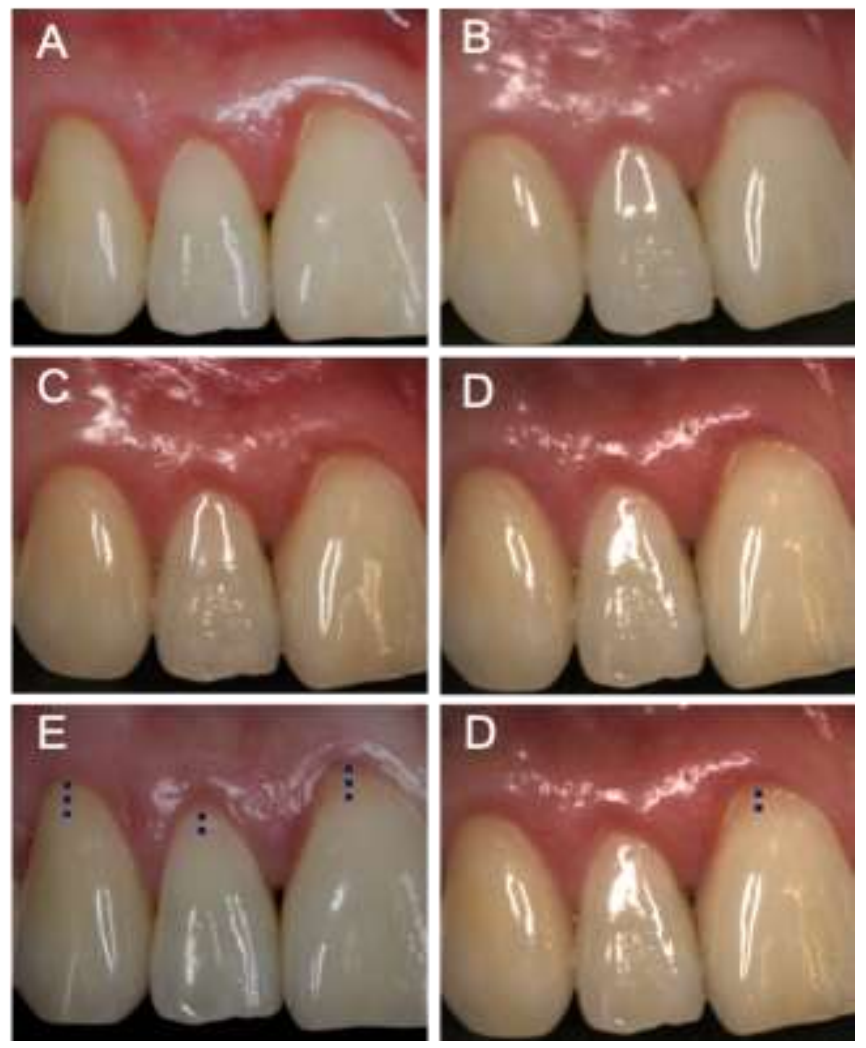

Source: Authors (2019).

\section{Discussion}

The present prospective case series evaluated the stability of $\mathrm{CM}+\mathrm{CAF}$ for RC treatment of multiple gingival recessions in esthetic areas after 24 months. Clinical outcomes showed a significant reduction of GRD, satisfactory RC percentage, and CAL gain after this period. Furthermore, PROMs assessment also showed significant results with an important impact on the quality of life, a significant reduction in hypersensitivity and substantial improvement in esthetic scores. 
Figure 3: Left side trend of clinical changes on GR at 3(A), 6(B), 12(C) and 24(D) months. E and D changes at baseline to the last follow up.
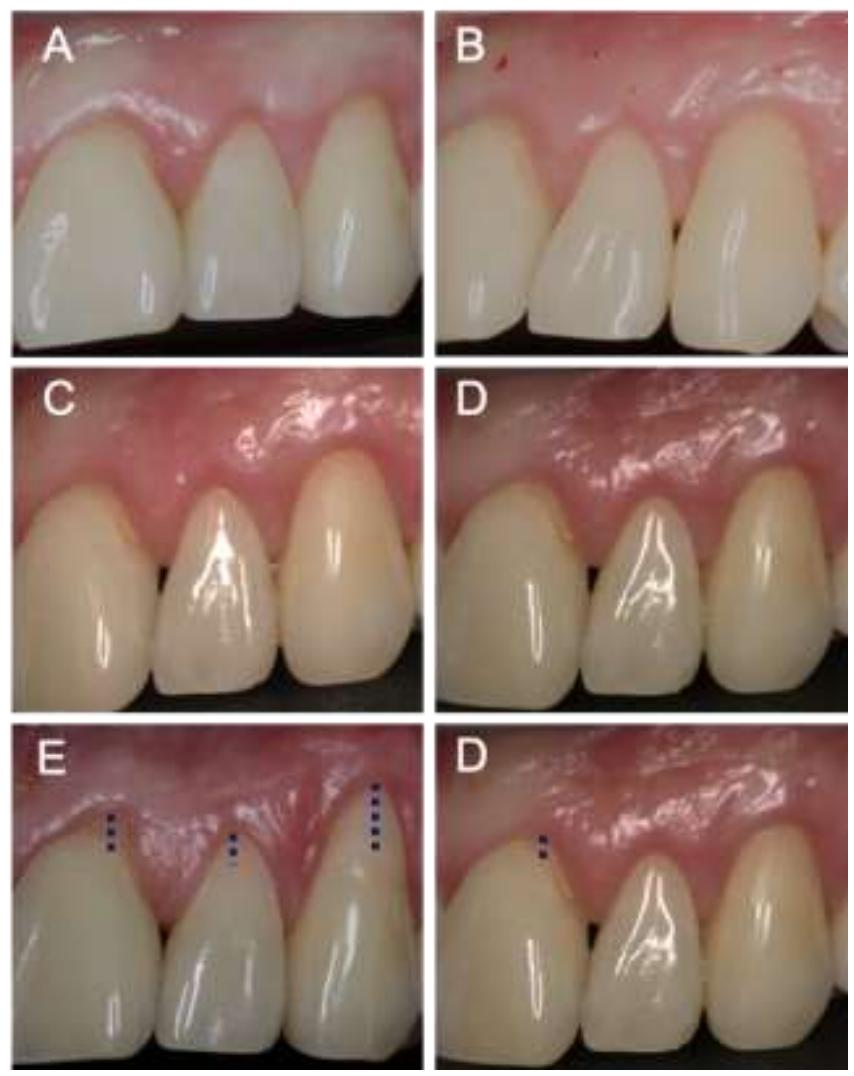

Source: Authors (2019).

A recent systematic review (Moraschini et al., 2019) compared results of CM + CAF to CAF alone in the treatment of RT1 gingival recessions. The results were based on 9 studies showing significant RC and improvement in GT and KTW for $\mathrm{CM}+\mathrm{CAF}$ group. However, considering the included studies, the follow-up time was 12 months. The Consensus Report of European Workshop on Periodontology strongly advises the long-term evaluation for clinical outcomes stability on GR treatments (Palmer \& Cortellini, 2008). The present case series demonstrated that a longer evaluation time is necessary, since CAL measurement had a second significant improvement from 12 to 24 months. Only two articles using CM for GR treatments presented follow-ups with more than 2 years (Jepsen et al., 2017; McGuire \& Scheyer, 2016). Nevertheless, these studies were conducted for localized GR. Until this moment, there is no scientific evidence demonstrating long-term stability of CM for multiple GR in esthetic areas. Multiple GR are more challenging defects due to a larger surgical field and anatomical variations, such as prominent roots, shallow vestibules, and defect sizes (Graziani et al., 2014). Moreover, biomaterials scaffolds and autogenous grafts present different clinical behaviors, being the main reason why SCTG remains the gold standard treatment (Chambrone et al., 2019). SCTG techniques present a limitation of the quantity of donor tissue and are related to superior morbidity and increased surgical time (Zuhr et al., 2014). Therefore, the use of CM as an alternative for SCTG on multiple GR should be more carefully studied, especially in a long-term evaluation. Despite the limited number of patients, the present case series suggests that CM + CAF is a reliable alternative treatment for RT1 multiple GR, demonstrating improvement in clinical outcomes, PROMs, and stability after 24 months. 
Figure 4: RCA- right canine group; RLI- right lateral incisor group; RCI- right central incisor group; LCI- left central incisor group; LLI- left lateral incisor group; LCA- left canine group. Mean RC evaluation per groups of correspondent teeth over the follow-up time. Groups RCA and LCA achieved the highest RC, whereas group LCI had the lowest RC over time.

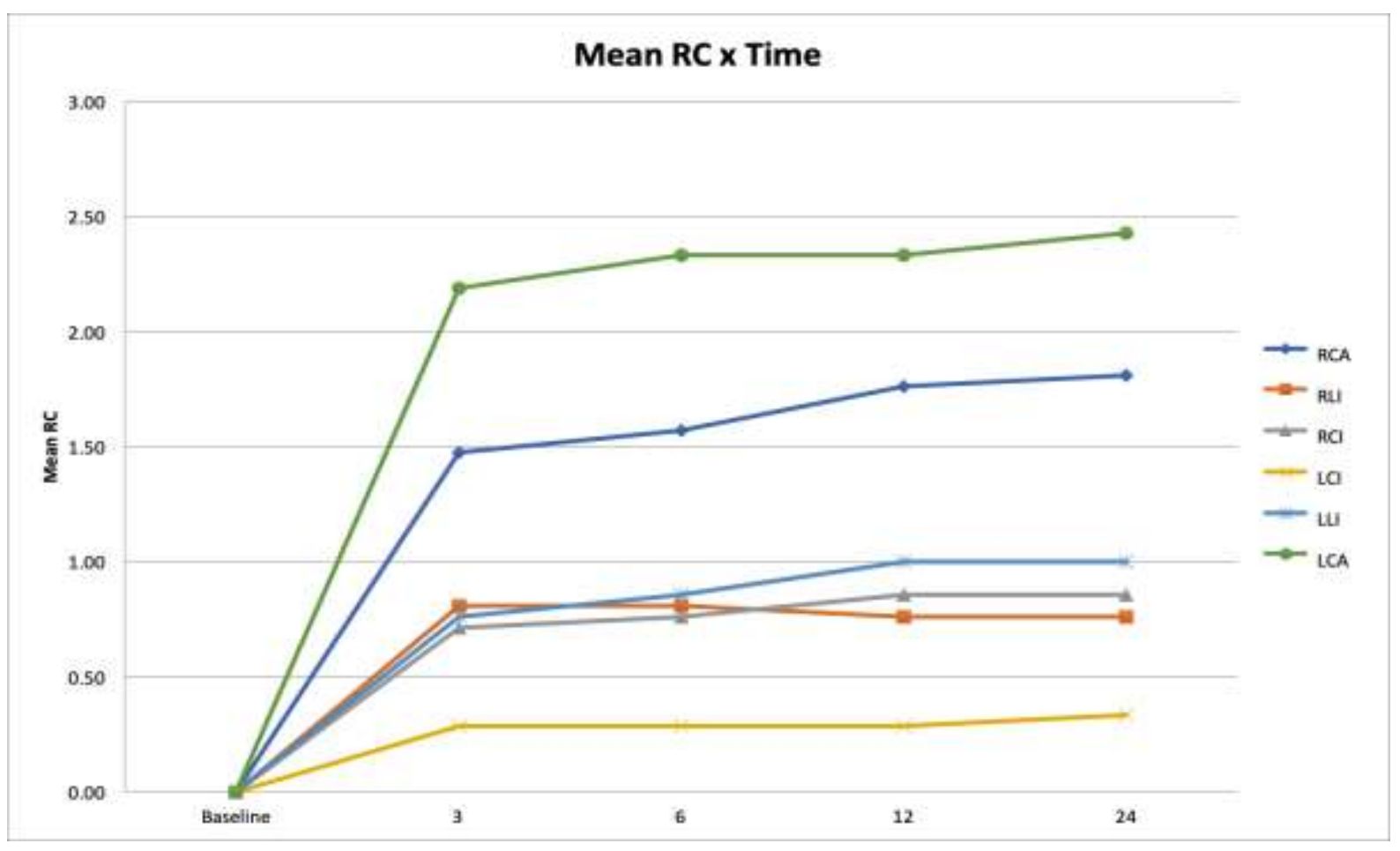

Source: Authors (2021).

Table 2: Qualitative analysis by OHIP-14 questionnaire. Over the follow-up time the numbers decreased, showing a great impact on patient's quality of life. The reduction at baseline to the last follow-up period had 18.1 of strength ( $p<0.05)$, presenting a significant improvement in patient's perception. $\mathbf{D}=$ dimensions 1 to 7 for the OHIP-14 calculation.

\begin{tabular}{|c|c|c|c|c|c|c|c|c|}
\hline \multirow{2}{*}{$\begin{array}{l}\text { Follow up } \\
\text { time }\end{array}$} & \multicolumn{8}{|c|}{ OHIP-14 Dimensions } \\
\hline & D1 & D2 & D3 & D4 & D5 & D6 & D7 & TOTAL \\
\hline Baseline & 0.32 & 1.10 & 0.87 & 0.72 & 0.81 & 0.33 & 0.16 & 4.30 \\
\hline $3 \mathrm{mo}$ & 0.05 & 0.35 & 0.11 & 0.15 & 0.27 & 0.19 & 0.04 & 1.13 \\
\hline $6 \mathrm{mo}$ & 0.05 & 0.24 & 0.24 & 0.14 & 0.26 & 0.24 & 0.09 & 1.26 \\
\hline $12 \mathrm{mo}$ & 0.05 & 0.20 & 0.21 & 0.17 & 0.15 & 0.16 & 0.09 & 1.03 \\
\hline $24 \mathrm{mo}$ & 0.04 & 0.17 & 0.14 & 0.14 & 0.10 & 0.11 & 0.08 & 0.78 \\
\hline
\end{tabular}


Table 3: Qualitative analysis by VAS scale (mean). Patient's score showed a significant improvement on VAS line. At the last follow-up time, esthetic perception, chewing and brushing capacity presented increased score. In addition, hypersensitivity and surgical pain/discomfort demonstrated a great reduction, showing better impact on life.

\begin{tabular}{|c|c|c|c|c|c|}
\hline \multirow[b]{2}{*}{ Variables analyzed } & \multicolumn{5}{|c|}{ Follow up time } \\
\hline & Baseline & $3 \mathrm{mo}$ & $6 \mathrm{mo}$ & $12 \mathrm{mo}$ & $24 \mathrm{mo}$ \\
\hline Esthetics & 4.5 & 7.6 & 7.8 & 7.8 & 8.2 \\
\hline Pain/discomfort & - & 7.8 & 7.1 & 7.6 & 7.2 \\
\hline Chewing capacity & - & 5.8 & 7.1 & 8.4 & 8.6 \\
\hline Brushing capacity & - & 6.4 & 7.1 & 8.4 & 8.6 \\
\hline Hypersensitivity & 6.2 & 4.6 & 3.1 & 3.4 & 3.4 \\
\hline
\end{tabular}

Source: Authors (2021).

Esthetics related to root exposure reveals a major impact on a patient's quality of life, being responsible for an elevated demand for patients seeking treatment. Several clinical studies used CM for GR treatment in mandible or maxilla, anterior or posterior areas (AlSarhan et al., 2019), but not a specific evaluation for multiple GR in the esthetic area (upper canines, central and lateral incisors). A recent split-mouth study compared SCTG to CM for multiple GR located on the maxilla, but not specifically in anterior teeth (Nahas et al., 2019). A recent study (Pelekos et al., 2019) compared SCTG to CM + CAF for multiple GR, in different intraoral sites, including mandible and maxilla. Results showed superior RC and esthetic scores for the SCTG group. However, better outcomes were found in the CM group for soft tissue texture and marginal tissue contour. These results are in accordance with the present study, showing that CM + CAF for multiple GR could be a viable alternative for esthetic areas. CM substitutes have been widely studied as an alternative for SCTG, aiming at reducing the number of surgeries (multiple GR) and intraoral sites (donor site). CM demonstrated important outcomes considering decreased postoperative morbidity and painkillers intake (Fu et al., 2012). Moreover, CM showed decreased surgical time, unlimited donor tissue, and high esthetics scores (Sanz et al., 2009).

$\mathrm{CAF}$ alone is an alternative to avoid the palatal approach despite being indicated only when sites present keratinized tissue (Baldi et al., 1999). Nevertheless, superior outcomes are reported when CAF is associated with CM compared to CAF alone (Huang et al., 2019). Rotundo (2019) showed similar outcomes for CM + CAF and CAF alone on RT1 gingival recessions. However, $\mathrm{CM}+\mathrm{CAF}$ demonstrated a superior gain of GT and $47 \%$ of CAF alone treated sites presented a decrease of GT $(<1 \mathrm{~mm})$ against $21 \%$ of CM + CAF group sites. The authors concluded that CM might be a predictable alternative for gingival deformities and thin phenotypes when compared to CAF alone. The results from the present study failed to present statistical improvement of GT, but this parameter was maintained over 2 years, with no decreased outcomes.

Another interesting analysis was the comparison of $\mathrm{RC}$ per group of teeth over the follow-up periods. Canines presented superior MRC compared to lateral and central incisors. The surgical technique employed may have some influence on these outcomes, since the papillae of central incisors were preserved and tunneled. The canine area is distant from the tunneled area, allowing more effective coronal flap displacement with less tension. In a recent study (Santamaria et al., 2017), the authors observed better RC outcomes for CAF in comparison to the tunnel technique. 
A recent meta-analysis (Huang et al., 2019) showed significant results on CAL measurement for CM + CAF group compared to CAF alone. However, no significant changes were found on KTW and PD assessments, presenting similar results for both groups. This evidence endorses the outcomes from the present study, whereas the CAL measure had two statistical changes over the follow-up time, demonstrating a satisfactory behavior of the CM on the recipient site.

Few studies compared SCTG to CM + CAF for PROMs and their results were quite similar (Aroca et al., 2013; Tonetti et al., 2018). Overall, these studies showed a significant reduction in hypersensitivity, surgical pain/discomfort, and surgical time for the CM + CAF group. Other studies (Jepsen et al., 2017; Sangiorgio et al., 2017; Stefanini et al., 2016) compared $\mathrm{CM}+\mathrm{CAF}$ to $\mathrm{CAF}$ alone, demonstrating no statistical difference between groups and revealing a great impact on patients' quality of life for both groups. Indeed, in the present study CM + CAF demonstrated excellent scores for esthetics and an important reduction in hypersensitivity and surgical pain/discomfort. VAS and validated questionnaires are the most used tools to assess PROMs. OHIP-14 seems to be an interesting questionnaire for the impact of quality life on GR treatment and an important tool to evaluate the patient's perception over time. Unfortunately, there is a lack of studies with PROMs in a longterm evaluation.

Despite the limitations of a case series, the present study demonstrated that $\mathrm{CM}$ is a reliable alternative treatment for multiple GR in esthetic areas. Besides, the outcomes obtained were maintained over time and these findings may encourage future researches to assess tissue substitutes in longer evaluation time.

\section{Conclusion}

Within the limits of the present study, the use of CM on Cairo's RT1 multiple gingival recessions in esthetic areas demonstrated positive clinical outcomes and PROMs after 24 months. Long-term randomized clinical trials should be conducted to support the present findings.

\section{References}

AlSarhan, M. A., Al Jasser, R., Tarish, M. A., AlHuzaimi, A. I., \& Alzoman, H. (2019). Xenogeneic collagen matrix versus connective tissue graft for the treatment of multiple gingival recessions: A systematic review and meta-analysis. Clinical and experimental dental research, 5(5), 566-579. https://doi.org/10.1002/cre2.210

Armitage G. C. (1999). Development of a classification system for periodontal diseases and conditions. Annals of periodontology, 4(1), 1-6. https://doi.org/10.1902/annals.1999.4.1.1

Aroca, S., Molnár, B., Windisch, P., Gera, I., Salvi, G. E., Nikolidakis, D., \& Sculean, A. (2013). Treatment of multiple adjacent Miller class I and II gingival recessions with a Modified Coronally Advanced Tunnel (MCAT) technique and a collagen matrix or palatal connective tissue graft: a randomized, controlled clinical trial. Journal of clinical periodontology, 40(7), 713-720. https://doi.org/10.1111/jcpe.12112

Baldi, C., Pini-Prato, G., Pagliaro, U., Nieri, M., Saletta, D., Muzzi, L., \& Cortellini, P. (1999). Coronally advanced flap procedure for root coverage. Is flap thickness a relevant predictor to achieve root coverage? A 19-case series. Journal of periodontology, 70(9), 1077-1084. https://doi.org/10.1902/jop.1999.70.9.1077

Cairo, F., Nieri, M., Cincinelli, S., Mervelt, J., \& Pagliaro, U. (2011). The interproximal clinical attachment level to classify gingival recessions and predict root coverage outcomes: an explorative and reliability study. Journal of clinical periodontology,38(7), 661-666. https://doi.org/10.1111/j.1600051X.2011.01732.X

Cairo F. (2017). Periodontal plastic surgery of gingival recessions at single and multiple teeth. Periodontology 2000, 75(1), 296-316. https://doi.org/10.1111/prd.12186

Chambrone, L., Ortega, M., Sukekava, F., Rotundo, R., Kalemaj, Z., Buti, J., \& Prato, G. (2019). Root coverage procedures for treating single and multiple recession-type defects: An updated Cochrane systematic review. Journal of periodontology, 90(12), 1399-1422. https://doi.org/10.1002/JPER.19-0079

Fu, J. H., Su, C. Y., \& Wang, H. L. (2012). Esthetic soft tissue management for teeth and implants. The journal of evidence-based dental practice, 12(3 Suppl), 129-142. https://doi.org/10.1016/S1532-3382(12)70025-8

Graziani, F., Gennai, S., Roldán, S., Discepoli, N., Buti, J., Madianos, P., \& Herrera, D. (2014). Efficacy of periodontal plastic procedures in the treatment of multiple gingival recessions. Journal of clinical periodontology, 41 Suppl 15, S63-S76. https://doi.org/10.1111/jcpe.12172 
Huang, J. P., Liu, J. M., Wu, Y. M., Chen, L. L., \& Ding, P. H. (2019). Efficacy of xenogeneic collagen matrix in the treatment of gingival recessions: A systematic review and meta-analysis. Oral diseases, 25(4), 996-1008. https://doi.org/10.1111/odi.12949

Jepsen, K., Stefanini, M., Sanz, M., Zucchelli, G., \& Jepsen, S. (2017). Long-Term Stability of Root Coverage by Coronally Advanced Flap Procedures. Journal of periodontology, 88(7), 626-633. https://doi.org/10.1902/jop.2017.160767

McGuire, M. K., \& Scheyer, E. T. (2010). Xenogeneic collagen matrix with coronally advanced flap compared to connective tissue with coronally advanced flap for the treatment of dehiscence-type recession defects. Journal of periodontology, 81(8), 1108-1117. https://doi.org/10.1902/jop.2010.090698

McGuire, M. K., \& Scheyer, E. T. (2016). Long-Term Results Comparing Xenogeneic Collagen Matrix and Autogenous Connective Tissue Grafts with Coronally Advanced Flaps for Treatment of Dehiscence-Type Recession Defects. Journal of periodontology,87(3), 221-227. https://doi.org/10.1902/jop.2015.150386

Moraschini, V., de Almeida, D., Sartoretto, S., Bailly Guimarães, H., Chaves Cavalcante, I., \& Diuana Calasans-Maia, M. (2019). Clinical efficacy of xenogeneic collagen matrix in the treatment of gingival recession: a systematic review and meta-analysis. Acta odontologica Scandinavica, 77(6), 457-467. https://doi.org/10.1080/00016357.2019.1588372

Nahas, R., Gondim, V., Carvalho, C. V., Calderero, L. M., Rosa, E. F., Sakiyama, T., César Neto, J. B., Pannuti, C. M., \& Romito, G. A. (2020). Treatment of multiple recessions with collagen matrix versus connective tissue: a randomized clinical trial. Brazilian oral research, 33, e123. https://doi.org/10.1590/18073107bor-2019.vol33.0123

Oates, T. W., Robinson, M., \& Gunsolley, J. C. (2003). Surgical therapies for the treatment of gingival recession. A systematic review. Annals of periodontology, 8(1), 303-320. https://doi.org/10.1902/annals.2003.8.1.303

Oliveira, B. H., \& Nadanovsky, P. (2005). Psychometric properties of the Brazilian version of the Oral Health Impact Profile-short form. Community dentistry and oral epidemiology, 33(4), 307-314. https://doi.org/10.1111/j.1600-0528.2005.00225.x

Palmer, R. M., Cortellini, P., \& Group B of European Workshop on Periodontology (2008). Periodontal tissue engineering and regeneration: Consensus Report of the Sixth European Workshop on Periodontology. Journal of clinical periodontology,35(8 Suppl), 83-86. https://doi.org/10.1111/j.1600051X.2008.01262.X

Pelekos, G., Lu, J. Z., Ho, D., Graziani, F., Cairo, F., Cortellini, P., \& Tonetti, M. S. (2019). Aesthetic assessment after root coverage of multiple adjacent recessions with coronally advanced flap with adjunctive collagen matrix or connective tissue graft: Randomized clinical trial. Journal of clinical periodontology, 46(5), 564-571. https://doi.org/10.1111/jcpe.13103

Rotundo, R., Genzano, L., Patel, D., D'Aiuto, F., \& Nieri, M. (2019). Adjunctive benefit of a xenogenic collagen matrix associated with coronally advanced flap for the treatment of multiple gingival recessions: A superiority, assessor-blind, randomized clinical trial. Journal of clinical periodontology, 46(10), 10131023. https://doi.org/10.1111/jcpe.13168

Sangiorgio, J., Neves, F., Rocha Dos Santos, M., França-Grohmann, I. L., Casarin, R., Casati, M. Z., Santamaria, M. P., \& Sallum, E. A. (2017). Xenogenous Collagen Matrix and/or Enamel Matrix Derivative for Treatment of Localized Gingival Recessions: A Randomized Clinical Trial. Part I: Clinical Outcomes. Journal of periodontology, 88(12), 1309-1318. https://doi.org/10.1902/jop.2017.170126

Santamaria, M. P., Neves, F., Silveira, C. A., Mathias, I. F., Fernandes-Dias, S. B., Jardini, M., \& Tatakis, D. N. (2017). Connective tissue graft and tunnel or trapezoidal flap for the treatment of single maxillary gingival recessions: a randomized clinical trial. Journal of clinical periodontology, 44(5), 540-547. https://doi.org/10.1111/jcpe.12714

Sanz, M., Lorenzo, R., Aranda, J. J., Martin, C., \& Orsini, M. (2009). Clinical evaluation of a new collagen matrix (Mucograft prototype) to enhance the width of keratinized tissue in patients with fixed prosthetic restorations: a randomized prospective clinical trial. Journal of clinical periodontology, 36(10), 868-876. https://doi.org/10.1111/j.1600-051X.2009.01460.x

Slade G. D. (1997). Derivation and validation of a short-form oral health impact profile. Community dentistry and oral epidemiology, 25(4), 284-290. https://doi.org/10.1111/j.1600-0528.1997.tb00941.x

Stefanini, M., Jepsen, K., de Sanctis, M., Baldini, N., Greven, B., Heinz, B., Wennström, J., Cassel, B., Vignoletti, F., Sanz, M., Jepsen, S., \& Zucchelli, G. (2016). Patient-reported outcomes and aesthetic evaluation of root coverage procedures: a 12-month follow-up of a randomized controlled clinical trial. Journal of clinical periodontology, 43(12), 1132-1141. https://doi.org/10.1111/jcpe.12626

Tonetti, M. S., Cortellini, P., Pellegrini, G., Nieri, M., Bonaccini, D., Allegri, M., Bouchard, P., Cairo, F., Conforti, G., Fourmousis, I., Graziani, F., Guerrero, A., Halben, J., Malet, J., Rasperini, G., Topoll, H., Wachtel, H., Wallkamm, B., Zabalegui, I., \& Zuhr, O. (2018). Xenogenic collagen matrix or autologous connective tissue graft as adjunct to coronally advanced flaps for coverage of multiple adjacent gingival recession: Randomized trial assessing non-inferiority in root coverage and superiority in oral health-related quality of life. Journal of clinical periodontology, 45(1), 78-88. https://doi.org/10.1111/jcpe.12834

Zucchelli, G., \& De Sanctis, M. (2000). Treatment of multiple recession-type defects in patients with esthetic demands. Journal of periodontology, 71(9), 1506-1514. https://doi.org/10.1902/jop.2000.71.9.1506

Zuhr, O., Bäumer, D., \& Hürzeler, M. (2014). The addition of soft tissue replacement grafts in plastic periodontal and implant surgery: critical elements in design and execution. Journal of clinical periodontology, 41 Suppl 15, S123-S142. https://doi.org/10.1111/jcpe.12185

Wennström J. L. (1996). Mucogingival therapy. Annals of periodontology, 1(1), 671-701. https://doi.org/10.1902/annals.1996.1.1.671 